\title{
A Feasibility Study for the Optimized Development of Renewable Air-Conditioning for Different Climatic Conditions
}

\author{
Tosin T. Oye \\ Edinburgh Napier University, UK \\ E-mail: t.oye2@napier.ac.uk
}

Naren Gupta

Edinburgh Napier University, UK

E-mail:n.gupta@napier.ac.uk

Keng Goh

Edinburgh Napier University, UK

E-mail: k.goh@napier.ac.uk

Toyosi K. Oye

Edinburgh Napier University, UK

E-mail: t.oye@napier.ac.uk

Received: July 31, 2020 Accepted: August 26, 2020 Published: September 1, 2020

doi:10.5296/emsd.v9i3.17459 URL: https://doi.org/10.5296/emsd.v9i3.17459

\begin{abstract}
This paper aims to present renewable air-conditioning as a sustainable system for varied climatic conditions with the feasibility of optimization to reduce the level of energy consumption and the rate of carbon emissions. Extreme use of air-conditioning has caused substantial growth in the level of energy consumption and carbon emissions. This fact clarifies the requirement for considering improvement applications of renewable energy
\end{abstract}


sources for air-conditioning systems. The components of solar air-conditioning are studied and employed as the basis for system optimization. The approach this paper presented implements a key component-based modelling analysis of renewables and modelling concepts that the geometry of this air-conditioning is founded on. The optimized model is performed using Polysun program, a renewable system analysis tool. As an exercise in the system modelling, the principle component analysis also accounts for the renewables of air-conditioning in relation to the context of the application and with respect to their integration into the climatic conditions of London, Toulouse and Rome. This, in turn, allows for the interpretation of the findings on the significance of renewables in energy consumption and carbon emissions. It also allows for the generation of a sustainability-based system that can reduce the level of energy consumption and the rate of carbon emissions. In this way, this paper uncovers the significance of renewables as a source of clean energy and sustainable practice in air-conditioning. It also reveals the particular contribution they make to the levels of energy consumption and carbon emissions that not only tackles global warming but also combats climate change.

Keywords: Air-conditioning, Renewable energy, Energy consumption, Carbon emissions, Climatic condition, Climate change

\section{Introduction}

The utilization of air-conditioning has moved from being a luxury to becoming a necessity for many inhabitants in their daily lives because of life-threatening summer conditions. However, one of the most extreme troubles confronting humankind in the twenty-first century is energy. Non-renewable energy sources, such as petroleum, natural gas and coal, have been the fundamental energy assets for human culture. The consumption of non-renewable energy sources has caused and is still causing harm to the environment. By 2050, the request for energy could be twofold, or possibly threefold, as the worldwide populace develops and emerging districts grow their economics (Oye et al., 2020a; 2020b). This has recently raised concerns in sustainable development over climate change, global warming, accelerating environmental influences like ozone layer reduction, energy resources reduction, insufficient thermal comfort, health issues, high cost and possible supply problems. While air conditioning has mostly been applied as a result of improvements in living conditions, health and environmental problems associated with the use of air-conditioning systems frequently unfolds (Yu et al., 2008; Aftab et al., 2013; Yu and Lin, 2015; Gugulothua et al., 2015; Oye et al., 2020b).

Studies by IPCC (2007), Kjellstrom et al. (2009), Schulte and Chun (2009), Ford and Berrang-Ford (2011) and Oye et al., (2020b) suggest that worldwide climate change will escalate indoor and outdoor heat loads and can damage wellbeing and harm work profitability for many individuals. Recent studies subsequently revealed that the climate crises reality hit headline news when the UK experienced its warmest winter day in February with a high peak temperature of $38.7^{\circ} \mathrm{C}$ on July 25, 2019 in Cambridge (Watts, 2019). Moreover, Henning (2009) suggested that air-conditioning is a typical specialized answer for issues of expanding temperatures, which incorporates both humidity and temperature control of the indoor air 
environment. In any case, developing air-conditioning usage builds power utilization and increases the rate of energy consumption and carbon emissions if the source of energy is unrenewable, leading to climate change. The role of urban areas in sustainable development has turned out to be increasingly conspicuous because of the developing urban populace around the world (Dempsey et al., 2011; Oye et al., 2020b).

Ongoing investigations have shown that structures are accountable for the utilization of around forty percent of the essential energy and the outflow of about thirty-three percent of greenhouse gases on the planet. Similarly, established researchers have committed significant exertion to secure housing energy sustainability in two primary ways: those utilizing renewable energy for the remaining task and those lessening outside energy supply. In the two different ways, resources of solar assets are picking up acceptance since they increase energy autonomy and sustainability simultaneously, contributing almost zero effect on the environment (Gugulothua et al., 2015; Oye et al., 2020a). However, solar air-conditioning (SAC) involves changing thermal solar energy into conditioned air in the indoor environment. It embraces the universal air-conditioning task with more positive environmental effects and less energy usage. Solar cooling lessens power requirements, operational expenses and the emissions of greenhouse gases. The adverse effects of air-conditioning uncover the need for considering the use of renewable energy sources. Consequently, Hao and GhaffarianHoseini (2012), Gugulothua et al., (2015) and Oye et al., (2020b) proposed that it is essential to replace conventional energy with solar energy for the end goal of sustainable growth. Utilizing renewable energy sources for climate change mitigation, especially the generation of solar energy to power air conditioning to reduce the level of energy consumption and carbon emissions, is expected to produce sustainable future development zones and further climate resilience.

\section{The Requirement of Renewables-Based Systems}

Several studies suggest that the utilization of renewable energy is getting a lot of awareness, and considerable examinations are still required for various innovations. Moreover, the state-of-the-art total world energy utilization is displayed in Figure 1 (Ritchie and Roser, 2019). The expanding utilization of fossil fuels not only leads to the quick exhaustion of energy sources but also causes the production of destructive gases, which straightforwardly influences humankind. An outline of the immediate and circuitous impacts of climatic changes as a result of consuming fossil fuels are revealed in Figure 2 (Rafique and Rehman, 2018). Comprehending the concealed effects of fossil fuels and its impacts on the wellbeing of humans is crucial for evaluating the sustainability of air conditioning and reinforcing more noteworthy decisions for future energy generations. Sustainable systems should be considered with the feasibility of utilizing cleaner energy sources such as photovoltaic solar power.

Moreover, cooling represents a significant aspect of the energy used in buildings. With respect to the utilization of power for air conditioning, its interest is expanding quickly, as presented in Figure 3 (Holst, 2020). Nevertheless, the expanding utilization of air-conditioning innovation empowers the creation of elective cooling developments, which 


\section{Macrothink}

Environmental Management and Sustainable Development

ISSN 2164-7682

2020, Vol. 9, No. 3

can proficiently use renewable power, such as solar-controlled systems, for their task. Discrepancies in fossil fuel costs have offered stimulus to a dynamic quest for other power sources. The idea of using solar power for cold generation was introduced in 1869 by a French innovator of the original solar power (Mouchot, 1987). In any case, the primary solar cooling system was openly shown by a similar specialist at the General Presentation in Paris, 1878 (Mouchot, 1869). Also, ice fledglings were delivered by the system with an alkali-water ingestion chiller and an illustrative reflector. The solar cooling exhibits were continued as late as the 1980s. Subsequently, the open consideration was caught distinctly for quite a while. The most current revival of broad heat solar cooling exploration was made towards the start of the twenty-first century after the philosophies of joining electric-driven chillers and photovoltaics were spread among scientists (Oye et al., 2020a).

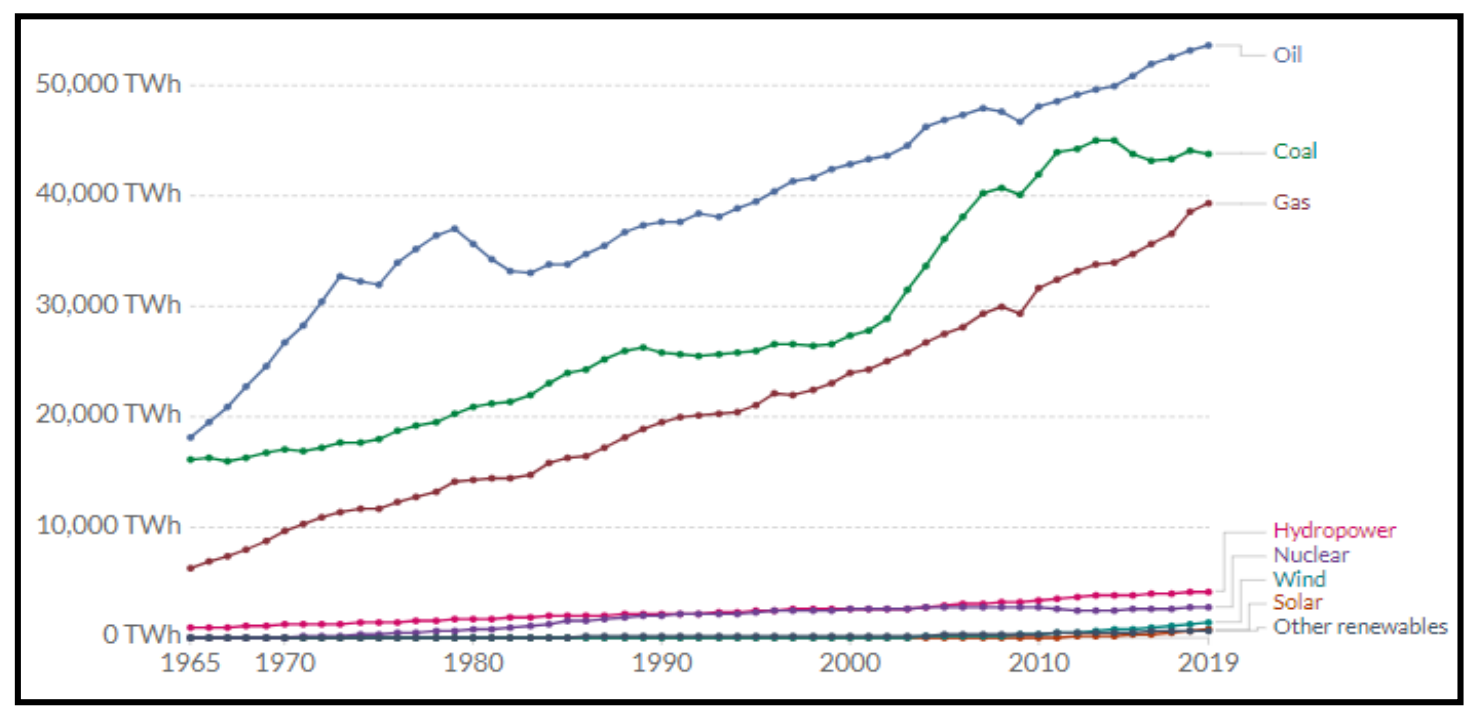

Figure 1. The world's consumption of energy (Ritchie and Roser, 2019)

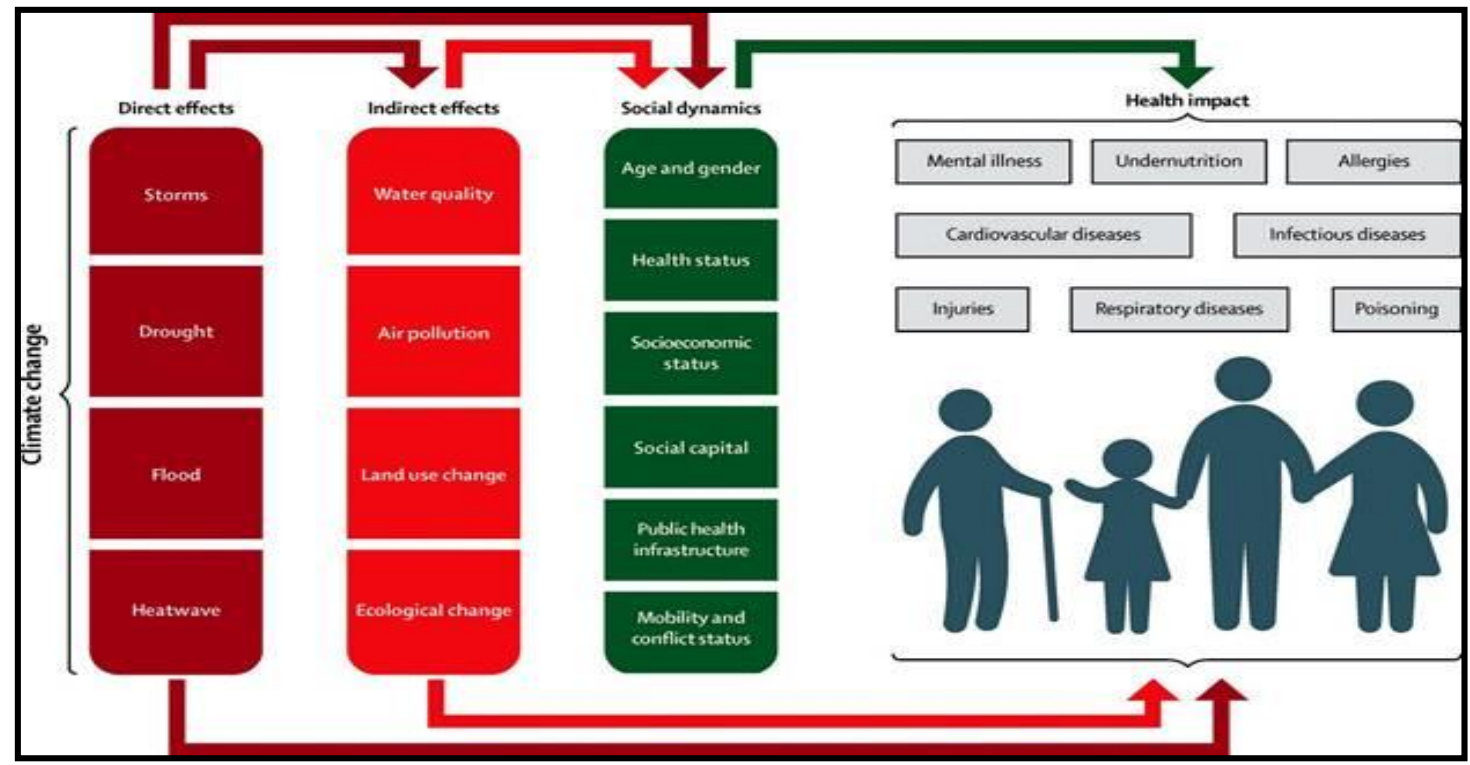

Figure 2. The climate change indirect and direct impacts on public health (Rafique and Rehman, 2018) 


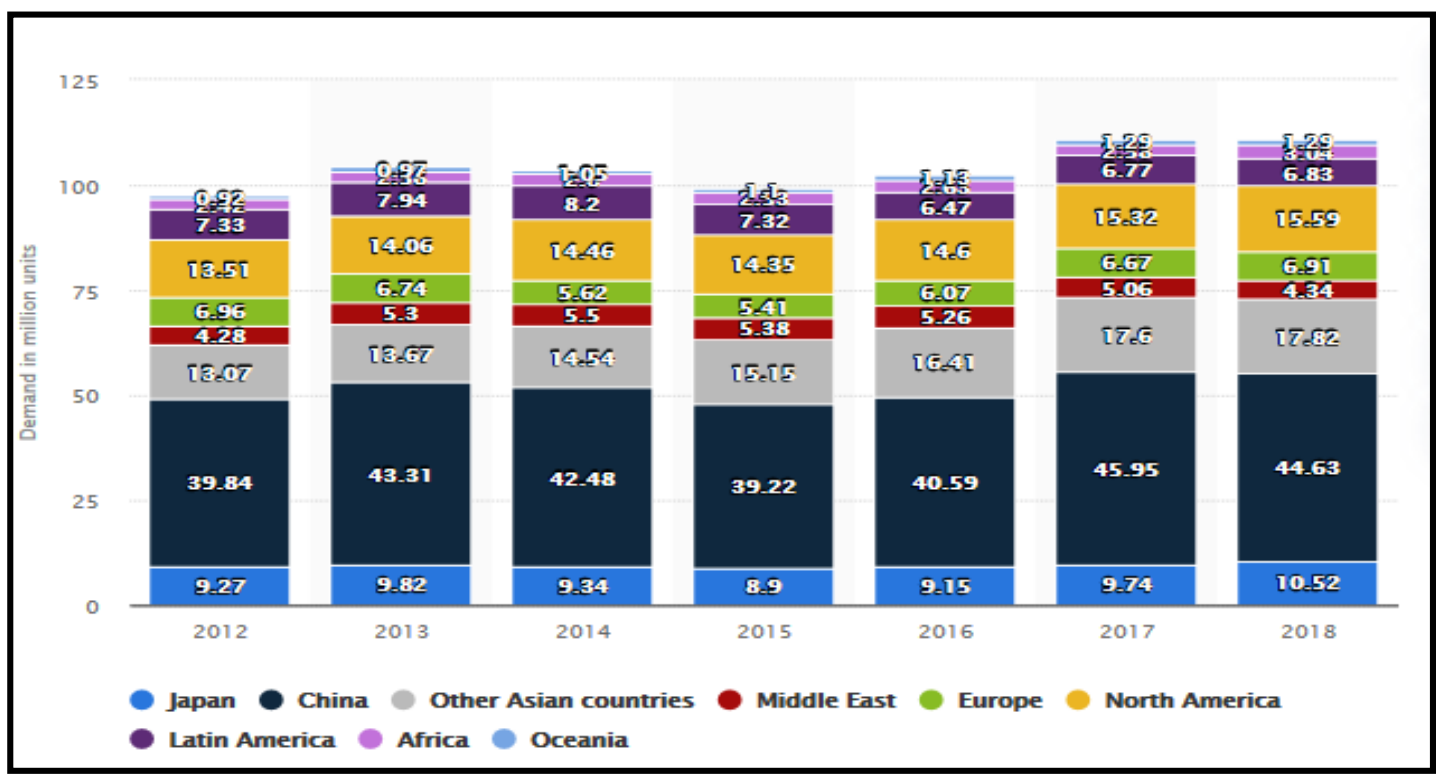

Figure 3. Air-conditioning demand worldwide from 2012 to 2018, by region (Holst, 2020)

Regularly rising wellbeing necessities in transportation and buildings makes the cooling mandate and in turn reinforces the development of cooling business sector across the globe. These wellbeing prerequisites are prompting the air-conditioning as a need in business structures and is not any longer observed as a luxury. With these grounds and the goal of reducing $\mathrm{CO}_{2}$ and energy, a rapid developing business sector of solar air-conditioning systems can be anticipated. This has remained generally unnoticed by a number of policy producers, incompletely on the grounds that cooling needs are customarily being met by electrical air conditioners, concealing the cooling component inside the structure's general power utilization (Mugnier, 2013; Holst, 2020). In Europe, research suggest that an increase in the portion of commercial buildings furnished with cooling systems is relied upon to reach minimum of sixty percent constantly by 2020 . The greatest potential cooling request in Europe if hundred percent of all valuable space would be air-conditioned is evaluated to be 1400 TWh cooling every year (Sanner et al., 2011; Holst, 2020).

Research studies by Mugnier (2013) and Sayigh (2018) suggest that solar cooling societies expects an upsurge of solar cooling growth in these days of emerging utilization of renewable energy sources. This increase in renewable energy sources execution in energy area receives support from European Union mandate and regularities of energy utilization (European Community, 2009). In any case, the ongoing structure order has a subtask of diminished cooling load growth (EC, 2010). Not a smaller amount of effect relating to "nearly zero energy buildings" has had an order 2020, which implies that immediate electricity utilizations and non-renewable energy source ought to typically diminish. Unquestionably, it is conceivable to lessen the carbon emissions and energy utilization of air-conditioning without decreasing the wellbeing level by utilizing renewable energy sources for the sustainability of the system. As indicated by Solar Heat Worldwide (2018), the European solar air-conditioning market has developed quickly during the most recent time which is the second largest solar cooling market as appeared in Figure 4. 


\section{Macrothink}

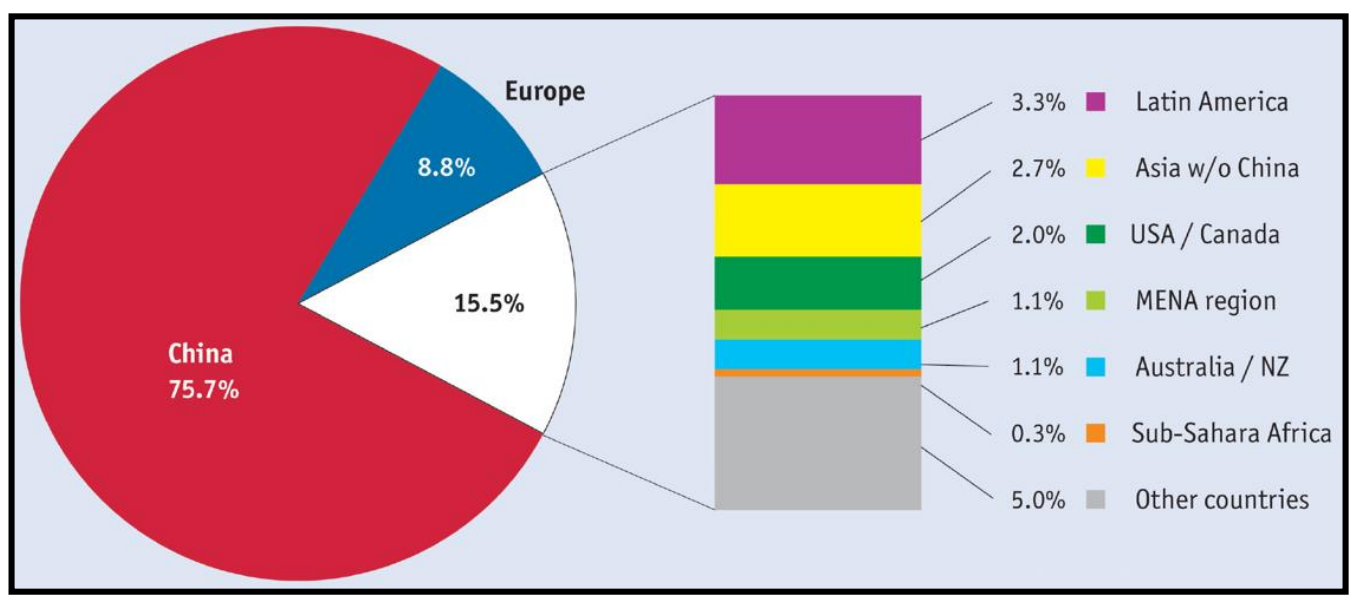

Figure 4. Solar cooling growth (Solar Heat Worldwide, 2018)

Subsequently, significant percentage of the universal solar cooling systems are mounted in Europe - most eminently in Italy, France, Germany and Spain (Mauthner and Weiss, 2014). Most of these systems are outfitted with evacuated tube collectors or level plate. On the other hand, China is the largest solar cooling market and a few models for warm cooling machines driven by intense solar warm energy were accounted for in other regions. The general number of systems introduced to date shows that solar cooling is yet a specialty showcase, hitherto a system which is growing (Mauthner and Weiss, 2014; Solar Heat Worldwide, 2018). Studies unveils that air-conditioning market conveyance pursues the development of existing environments. Little scale air-conditionings have a short lifetime (typically from two to five years), which infers persistent substitution of the components of such a scheme. Regardless of this, the market development is watched consistently in the most recent time as appeared in Figure 5.

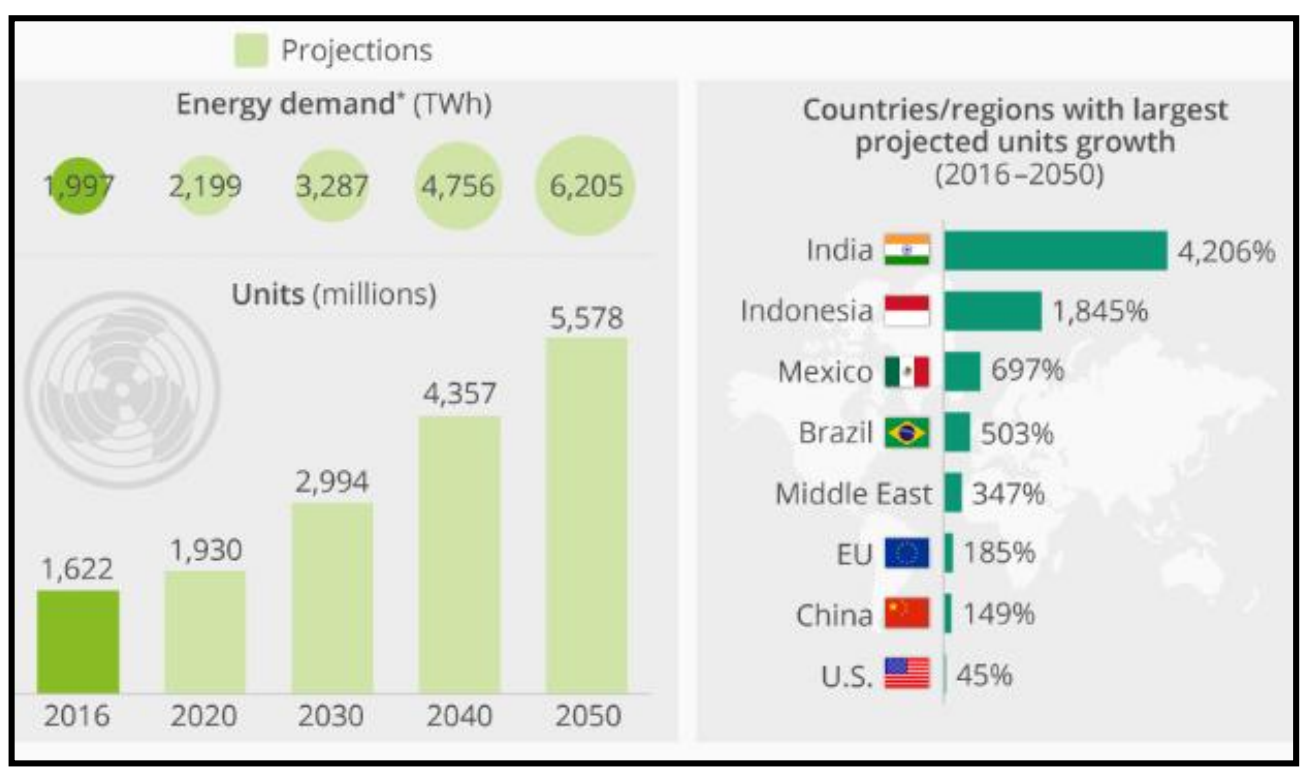

Figure 5. Conventional air-conditioning market situation (Armstrong, 2018)

Subsequently, little scale air-conditioning business sector estimate in EU is significantly increased in the time from the year 2016 to 2020; with greater projection of increase from 


\section{Ml Macrothink}

2030 to 2050. In the growth of the market, the impact of variable economic circumstance could be observed universally and particularly in EU. Dissemination of air-conditioning elements in the twenty-first century is diverted from advanced nations to dynamically industrializing districts; innovative appropriation patterns are currently apparently focused for the Asia locale. With respect to assembling, speeding up of air-conditioning manufacture turns out to be the primary focal point of the real Asian producers over the most recent twenty years (Vougiouklakis et al., 2008; Jakob, 2013; Armstrong, 2018).

According to Masson et al., (2014), the photovoltaic solar air-conditioning primary energy source is the power delivered by a photovoltaic cluster. The elements of photovoltaic establishment are contrarily corresponding to introductory interests. The value decrease for photovoltaic items in the most recent era is in nearness to ten percent a year and consistently, the least cost records per introduced photovoltaic ostensible power are set while all effects are considered for the system. Moreover, the world's total introduced photovoltaic limit was more than $23 \mathrm{GW}$ in late 2009. After a year it was $40.3 \mathrm{GW}$, having increased to $70.5 \mathrm{GW}$ before the finish of 2011. The $100 \mathrm{GW}$ imprint was gotten in 2012, and practically $138.9 \mathrm{GW}$ of PV had been introduced all around in 2013 - a sum fit for delivering at the rate of 160 terawatt hours (TWh) of power each year (Masson et al., 2014; Solar Heat Worldwide, 2020). For this power capacity is adequate to cover the yearly energy supply requirements of more than 45 million EU family units. This is additionally what might be compared to the power created through thirty-two huge coal energy plants. The worldwide collective introduced volume could have achieved $140 \mathrm{GW}$ if the extra 1.1 GW in China were considered in 2013 (Masson et al., 2014; Solar Heat Worldwide, 2020).

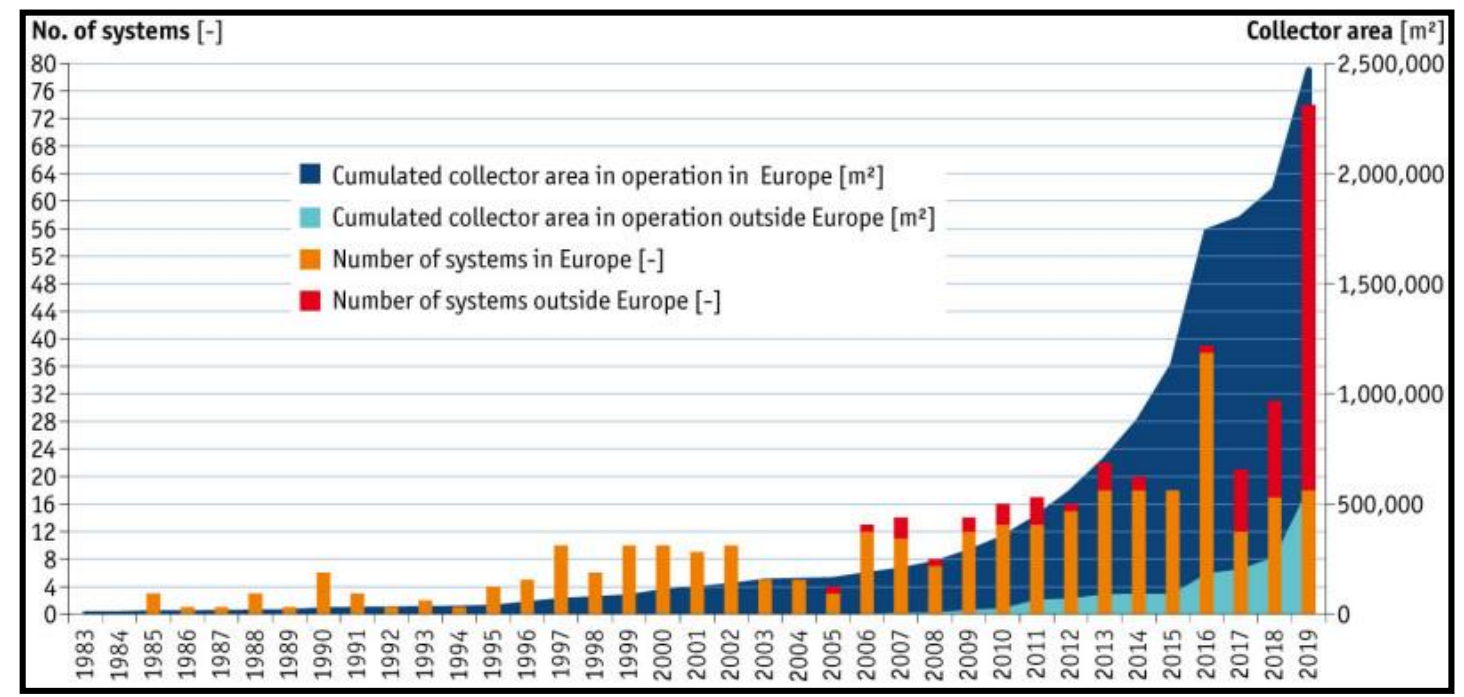

Figure 6. Installed capacity cumulative for worldwide development of photovoltaic (Solar Heat Worldwide, 2020) 


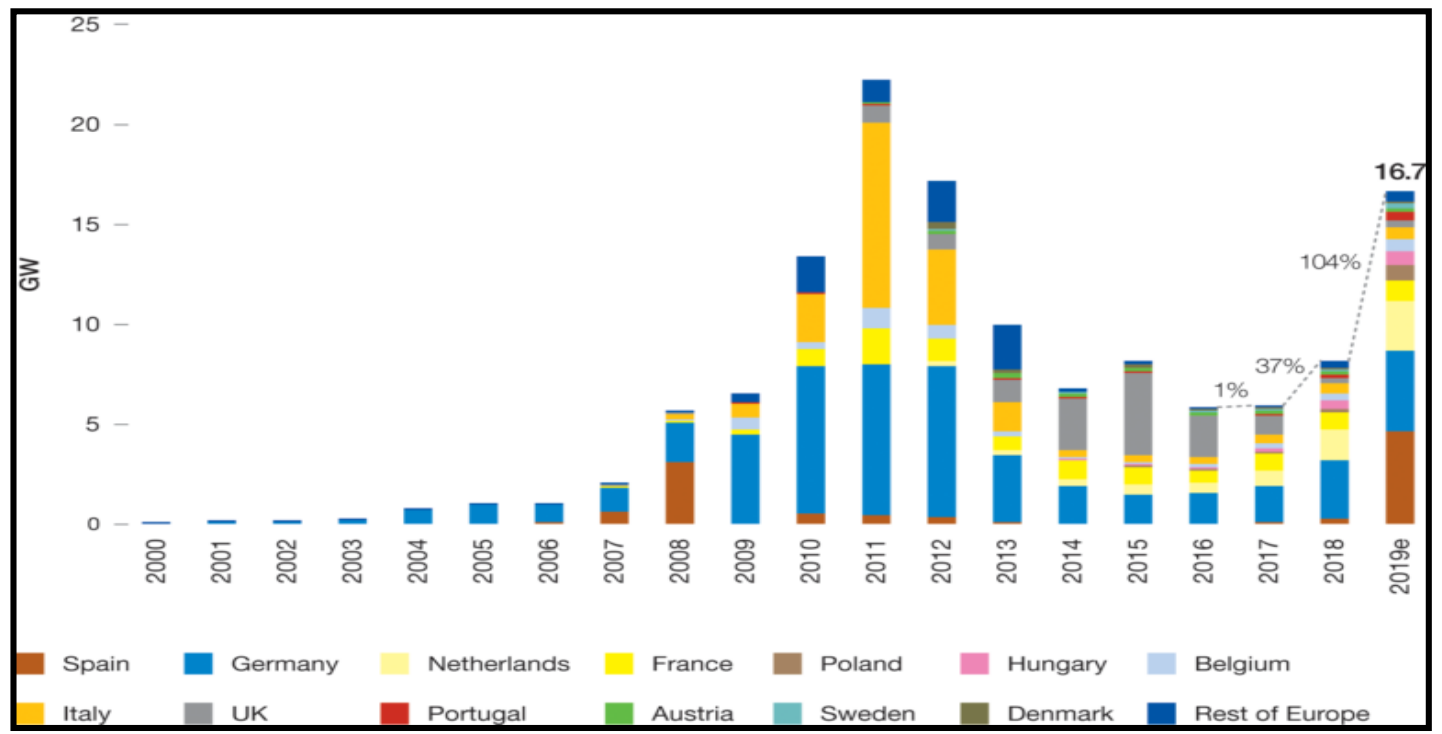

Figure 7. 2000 - 2019 annual installations worldwide development (Solar Power Europe 2020)

Research suggests that the EU remains the world's foremost district regarding the system collective introduced volume. This characterizes to around fifty-nine percent of the biosphere's total photovoltaic volume from seventy percent to around seventy-five percent of the world's volume. As delineated in Figure 6, nations outside Europe are developing quick (Solar Heat Worldwide, 2020). For the year 2019 was a record time for photovoltaic establishments with over 100\% solar market increase as illustrated in Figure 7 (Solar Power Europe, 2020). These statistics demonstrate that in 2018, the internationalization pattern of photovoltaic showcases detected was then complemented in the year 2019, with China leading the pack over EU as number one district for photovoltaic establishments.

\subsection{The Solar Air-conditioning}

Studies uncovered that solar adsorption systems have long-haul environmental advantages and noteworthy power effectiveness like the absorption solar air-conditioning (Islam and Morimoto, 2016). For they utilize regular refrigerants as depicted by Vasta et al., (2013) and can be determined by a low-temperature warmth source as explored by Hadj et al., (2015). Subsequently, various examinations have been centered around the structure of solar adsorption air-conditioning. In any case, their structure is intricate and a few constraints similar to the heat rejection, are difficult to be resolved utilizing old style apparatuses (Vasta et al., 2013). Research by Vasta et al., (2013) built up an active prototypical in Italy to mimic a solar cooling system fortified with a reinforcement element, adsorption chillers and a heat rejection component, which are determined by solar accumulators conveyed over a region of $27.52 \mathrm{~m}^{2}$ to cool a level structure region of $130 \mathrm{~m}^{2}$. Thusly, the examinations by Vasta et al., (2013) communicate the warm presentation of the solar accumulators as:

$$
\frac{Q}{A}=G\left(\eta_{0}-1.485 \frac{\left(T_{m}-T_{a}\right)}{G} 0.002 \frac{\left(T_{m}-T_{a}\right)^{2}}{G}\right.
$$


For $A$ is their area, $\eta_{0}$ is the ratio of the efficiency measured at actual admitted irradiance to vertical admitted irradiance, $G$ is the intensity of the solar radiation. $Q$ is the power of solar collectors, $T_{a}$ is the ambient temperature and $T_{m}$ is the collector average temperature. Also, 10001 of water is likewise cooled by the system and can be utilized in several actions. Nevertheless, the coefficient of performance of the chiller is small equated by the electric one: 0.35 and 2.5, discretely. They are calculated via equation (2) and (3) (Vasta et al., 2013).

$$
\begin{gathered}
C O P_{\text {chiller }}=\frac{Q_{e v}}{Q_{s}+Q_{\text {heater }}} \\
C O P_{\text {electric }}=\frac{Q_{e v}}{Q_{e l, t o t}}
\end{gathered}
$$

Consequently, $Q_{e l, t o t}$ is the overall electric utilization of the entire system mechanisms, $Q_{\text {heater }}$ is supplied power through the stoppage element, $Q_{s}$ is supplied power through the solar accumulators and $Q_{e v}$ is energy evaporation constituting the suitable outcome of the chiller. Similarly, the proportion amongst the entire energy needed through the whole system and the supplied energy via the warm air accumulators, named solar fraction is specified via equation (4) (Vasta et al., 2013).

$$
S F=\frac{Q_{S}}{Q_{S}+Q_{\text {heater }}}
$$

Furthermore, the establishment expenses are high and around $3942.45 \mathrm{kWh}$ electric power are spared every year. Alternative adsorption cooling system utilizing a rounded solar $1-\mathrm{m}^{2}$ twofold coated adsorber/ accumulator was structured according to research by Hadj et al., (2015). In the Sub-Sahara areas in Algeria, the primary target is to diminish the power utilization of cooling systems. In August, an energy saving of around 28.3 MWh cold be achieved (Hadj et al., 2015). On the other hand, the solar coefficient of performance is excessively low, around 0.21 .

Studies by Henning et al., (2001) unfurl that a decrease of the power utilization of about fifty percent was accomplished, particularly in wet and hot climates because of the utilization of solar power for the generation of cold. In like manner, Henning et al., (2001) exploit a customary cooling system with a drying-out cooling cycle that can be adjusted to the fixed solar cells to air-condition a household volume of $330 \mathrm{~m}^{3}$ utilizing $2 \mathrm{~m}^{3}$ heated water tank and $20 \mathrm{~m}^{2}$ level plate accumulator (Zhang et al., 2016), which can be utilized in domestic exercises. In any case, the coefficient of performance of the cooling system of 0.6 is low and the indoor climate does not satisfy normal wellbeing standards for couple of hours all through the cooling season. Another air-conditioning/ water system for structures is exhibited in the exploration studies by Jafari and Poshtiri (2017). It is established by a solar chiller area of 12 $\mathrm{m}^{2}$, a cooling channel area of $24 \mathrm{~m}^{2}$ and a solar-driven adsorption chiller, via which the hot air is disseminated and cooled in the assessment chamber, having volume of $200 \mathrm{~m}^{3}$ under moist and hot, and dry and hot climate. The coefficient of performance of the chiller and cyclic cooling limit achieved their most extreme qualities of around 0.71 and $16 \mathrm{~kW}$ discretely all through the day and somewhere in the range of 15 and $16 \mathrm{~h}$. This permitted diminishing the room temperature by 26.8 percent. In addition, the electric power used-up by the system is 
thirty-seven percent which is not as much as that used-up by a split inverter air conditioner partaking a similar cooling energy (Jafari and Poshtiri, 2017).

Thus, studies uncover that adsorption and absorption innovations can be consolidated in a similar air-conditioning to further improve its exhibition. As an issue of actualities, research studies by Buonomano et al., (2018) propose innovative solar poly-generation systems, grounded upon both absorption and adsorption chiller innovations encouraged by level thermal accumulators/ photovoltaic and dish-moulded absorbed rather than regular solar accumulators. Buonomano et al., (2018) built up a PC code to decide the ideal system arrangements considering the climatic conditions and working parameters. The systems are connected to inhabit office buildings situated in various climatic EU areas. The exploration studies by Buonomano et al., (2018) offered high temp water and power, as they guaranteed cooling and heating of the air-conditioned buildings. Nevertheless, this paper unfolds top optimisation possibilities of solar air-conditioning using a suitable modelling technique to reduce the level of energy consumption and rate of carbon emissions in different climatic conditions.

\section{The System Optimization Using Conceptual Modelling}

Research studies by Broman (1991) and Kandpal and Broman (2015) unfold that a number of software collections have been recognized well along in equivalent to TRNSYS, furthermost of them with a simple user associate and to some extent lessened functionality and majority of the software have been successfully applied in solar energy study (for example: Insel, PVSyst, Polysun, T*Sol, commercial, PVGIS, RETscren). Studies by Milrad (2013) likewise reveal that computer simulation software programs that is applied in general engineering (for example, Matlab, EES, Berkeley Madonna, Stella) are basically less appropriate for the study of solar energy because the software are extra multifaceted and possesses absolutely no built-in orientation or references to the systems of renewable energy. Therefore, the state-of-the-art Polysun Designer Version is employed for the optimized model of solar air-conditioning in this paper.

The adapted building is a household located in Rome, Italy. The chosen location is as a result of the hot temperate environment. Subsequently, $500 \mathrm{kj} / \mathrm{K} / \mathrm{m}^{2}$ is the capacity of heat and $0.5 \mathrm{~W} / \mathrm{K} \cdot \mathrm{m}^{2}$ is the proposed building coefficient total heat loss that basically commensurate with a regular insulated light of building construction. The key mechanisms of the photovoltaic solar air-conditioning are the modules of photovoltaic associated with an alternating/ direct current inverter, outdoor heat rejection unit, indoor cold distribution elements and electric-driven chiller. The modelling of the system comprises of the outdoor unit for warming the domestic hot water, the cold storage, and a hot storage (Oye et al., 2020b).

The silicon monocrystalline photovoltaic cells absorb power from the solar and convert it to electrical energy. The cells efficiency is $17.4 \%$ and each element size is $1.65 \mathrm{~m}^{2}$. The photovoltaic frameless elements are protected through solar glass of $5 \mathrm{~mm}$ having coating antireflection with the $9 \mathrm{~mm}$ overall width. For $14.77 \mathrm{~m}^{2}$ is the overall zone of nine installed photovoltaic components. Also, $285 \mathrm{kWp}$ is the extreme irradiation of minimal power of 
individual photovoltaic component, having $\pm 3 \%$ error. Likewise, $2.565 \mathrm{kWp}$ is the extreme irradiation of minimal ultimate entire photovoltaic array power. It matches to the $2.5 \mathrm{~kW}$ which is the cooling machine of extreme electrical power. Equally, $31.2 \mathrm{~V}$ is the current photovoltaic extreme power point component with $38.3 \mathrm{~V}$ as the voltage open circuit. For 8.7 $\mathrm{A}$ is the current of photovoltaic component and subsequently, 9.2A is the current short-circuit (Oye et al., 2020b). Also, the over-current shield is 18A, which is in-parallel and the entirely photovoltaic components are connected electrically. For $280.8 \mathrm{~V}$ is the entire voltage and $1000 \mathrm{~V}$ is the extreme voltage system range.

Photovoltaic components connection through the manufacturers' recommendation is sixty at serial connection maximum number. Manufacturer representative guarantees the categories of these photovoltaic units; however, there is lowest of ninety percent performance after ten years of usage and eighty percent after twenty-five years. Hence, in the calculations, photovoltaic minimal power reduction with time is considered. Likewise, $0.9 \%$ is the yearly efficiency reduction of the preceding annual's rate. Hereafter, the photovoltaic units unframed are aimed to be secured on the proposed roof area. For $15^{\circ}$ inclination to horizon are advised for photovoltaic units to be ascended. The roof examined is with a slope of $5^{\circ}$. This suffices angle aimed at connection of electric power beneath the elements. Aluminum is examined for sketching unframed components. The ascending of photovoltaic considered is designed in understanding of flexion defense with likely alterations owing to enlargement of the thermal. Flexion defense from uppermost and lowermost is planned concerning snow masses and winds respectively. Rubber gaskets amongst the mounting and photovoltaic elements are examined to permit expansion of the thermal alterations (Oye et al., 2020b).

\subsection{The System Dimension and Apparatus}

Exceptionally accurate estimating apparatus are theoretically employed from investigations. This apparatus and its position permit inspecting the operational scenario and specific primary parts of photovoltaic solar air-conditioning. The entire estimating strategies analyzed for the system model are controlled. For this scenario operation model, it is conceivable to screen and spare the information acquired during the system's activity in the information procurement program. Altogether, the photovoltaic solar air-conditioning system model is anticipated to contain one sensor of solar irradiation, one sensor of air pressure, four sensors for humidity, eight flow counters, six electricity counters and forty sensors for the temperature. Additionally, manual three flow meters, three sensors of manual pressure, and manual eight thermometers are studied for animate operation of the system's security monitoring. As a consequence, the sensor numbers and their class of accuracy in a standard system must be minimized as a result of simplification cause and economic or commercial basis.

Moreover, electric energy estimations are specified on the sides of direct current and alternating current. The photovoltaic voltage and the forthcoming current are estimated through meters incorporated into the inverter of the photovoltaic. Inverter-delivered parameters of alternating current power are estimated with alternating current, frequency and voltage meters, that are likewise coordinated into the inverter. For $0.01 \mathrm{~V}$ is the voltage 
estimations accuracy and $0.001 \mathrm{~A}$ is the estimations on the two sides. Incoming estimations of direct current and alternating current outgoing electrical energy are over with $1 \mathrm{~W}$ precision, and $0.01 \mathrm{~Hz}$ is the exactness at estimating recurrence. For the system model, three extra power meters are scrutinized which independently measure the power utilizations of heat pump, outdoor unit and supplementary pumps. For $1 \mathrm{Wh}$ is the electrical energy accuracy of the entire component estimations. Figure 8 presents the positional illustration of the system apparatus in the building.

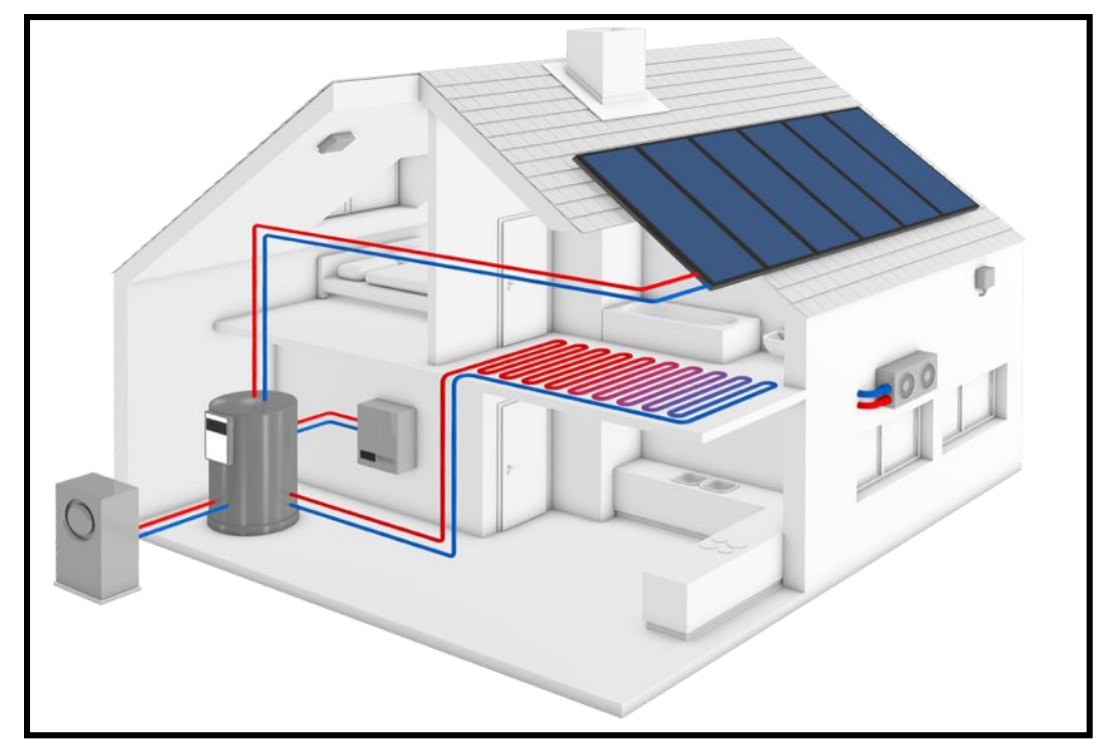

Figure 8. Positional illustration of the system apparatus

The specified dimensions are examined with the flow counters pull-type. Extremely accurate six counters of flow are examined for dimension of current over the key portions of the scenario system. The sensors of temperature typically estimate water, air and brine temperatures. Sensors of water temperature and saline solution are projected to be applied in an exceptional metal cases inside tanks and pipes, whereas possessing PT100 purpose thermometers resistance of $4 \times 0.25 \mathrm{~mm}^{2}$ wires of class A, having $5 \mathrm{~m}$ length of cable. The scope of temperature, having PT100 class A is basically $-70{ }^{\circ} \mathrm{C}$ in the direction of $+550^{\circ} \mathrm{C}$ and possess the actual precision after $0.15^{\circ} \mathrm{C}$ in the direction of $0.27^{\circ} \mathrm{C}$ which is basically in the solar air-conditioning temperature array of operation. Temperature and flow counters combination sensors permit thermal energy accounting.

In like manner, the heat pump possesses eleven coordinated B class of PT100 thermometers resistance, and two flow sensors for checking of energy flow interior control, having three current sensors for each stage. The pump likewise possesses switches that is of low and high weight. Likewise, the meteorological station typically makes it conceivable to decide the main parameter of climate conditions for the system model and it can be associated close to the photovoltaic components. The station is specified to incorporate sensors for estimating temperature of photovoltaic component, relative humidity of air, pressure of air and temperature of the outdoor air. For the system model, estimation scope apparatus relates to the climate vacillations. The temperature of the outdoor air of the selected region is examined 
with $0.2^{\circ} \mathrm{C}$ accuracy for modelling, whereas having $-20^{\circ} \mathrm{C}$ in the direction of $+50^{\circ} \mathrm{C}$ within the range of specified temperature. For $0.1 \%$ is the humidity relative air sensor resolution, albeit it gauges two percent accuracy from zero to one hundred percent in the entire range. Also, $1.5 \mathrm{hPa}$ is the air weight estimating accuracy from $300 \mathrm{hPa}$ in the direction of $1200 \mathrm{hPa}$ for the entire range. The most noteworthy second-class thermopile pyranometer is examined for estimating the irradiance of the solar power and proposed for shortwave worldwide radiation of solar energy estimations from $300 \mathrm{~nm}$ in the direction of $2800 \mathrm{~nm}$ within the range which is basically spectral. The detector thermopile estimates $2000 \mathrm{~W} / \mathrm{m}^{2}$ irradiance, whereas possessing $<18 \mathrm{~s}$ of reaction time and $10 \mu \mathrm{V} / \mathrm{W} / \mathrm{m}^{2}$ sensitivity characteristic, having $-10^{\circ} \mathrm{C}$ in the direction of $+4^{\circ} \mathrm{C}$ that shifts under five percent (Cooling Machine Manufactory, 2019). For $<1 \mathrm{~W} / \mathrm{m}^{2}$ is the irradiation of solar accuracy estimation. The temperature component is estimated with exactness of $1{ }^{\circ} \mathrm{C}$ from $-20^{\circ} \mathrm{C}$ in the direction of $+80^{\circ} \mathrm{C}$, in the fundamental range of temperature. The information is obtained by utilizing the state-of-the-art meteorological database.

\section{Result and Discussion}

The optimized development of the proposed system is performed using Polysun program in this paper. The window glazing ratio towards the area of the building wall is typically constant for the entirely structure margins and the infiltration and exchange rate are produced by natural ventilation. In the adopted location of Rome, the tilted angle of photovoltaic module is $45^{\circ}$, while the global irritation annual sum is $1432 \mathrm{kWh} / \mathrm{m}^{2}$. The annual photovoltaic energy production $\mathrm{DC}$ is $7,106.9 \mathrm{kWh}$ and the energy production $\mathrm{AC}$ is $6,468.5$ $\mathrm{kWh}$. However, the specific annual yield is $1,198 \mathrm{kWh} / \mathrm{kWp}$ and the annual outcome of $\mathrm{CO}_{2}$ emission savings is $3,470 \mathrm{~kg}$. In a cooling season, the photovoltaic electricity is produced with the total efficiency of the inverter all through the year. Albeit, middle May is the period of cooling up to the time of October for the precise cooling energy mandate. There is heat gain of the building in the cooling season, where there is solar gain via the windows, including stemming after the flow of heat via the envelope of the structure. For the infiltration, natural ventilation and the remaining inside heat gain is attained in the building. Successively, once the outside temperature is lesser than the inside temperature, increased percentage of the heat gain is rejected through the envelope of the structure, infiltration and natural ventilation.

Consequently, Figure 9 and Figure 10 unfolds the outcome of the energy production of photovoltaic AC with the sum of own electricity consumption from the consumption profiles and the electricity consumption of the thermal components. For the room air stays in the range of comfort temperature at photovoltaic solar air-conditioning performance. The air temperature excess above the set conditioning is decreased at performance of the system. Correspondingly, the required power is used up to operate the fluid pumps, outdoor unit and heat pump. A typical photovoltaic produced power is utilized for cold production via the heat pump. In the cooling season, the photovoltaic solar air-conditioning manufactures energy through the photovoltaic collection which remain used up in every consumers of the system's power. As a result, the photovoltaic solar air-conditioning can completely provide power independently with overall annual photovoltaic $\mathrm{CO}_{2}$ emission savings of $3,470 \mathrm{~kg}$ as presented in Figure 11. Additionally, the remaining produced power may be retained for 
future use. This suggests that optimization of top possibilities is concealed in the accessibility of the photovoltaic collection power together with the consumption of small electric power for cold production.

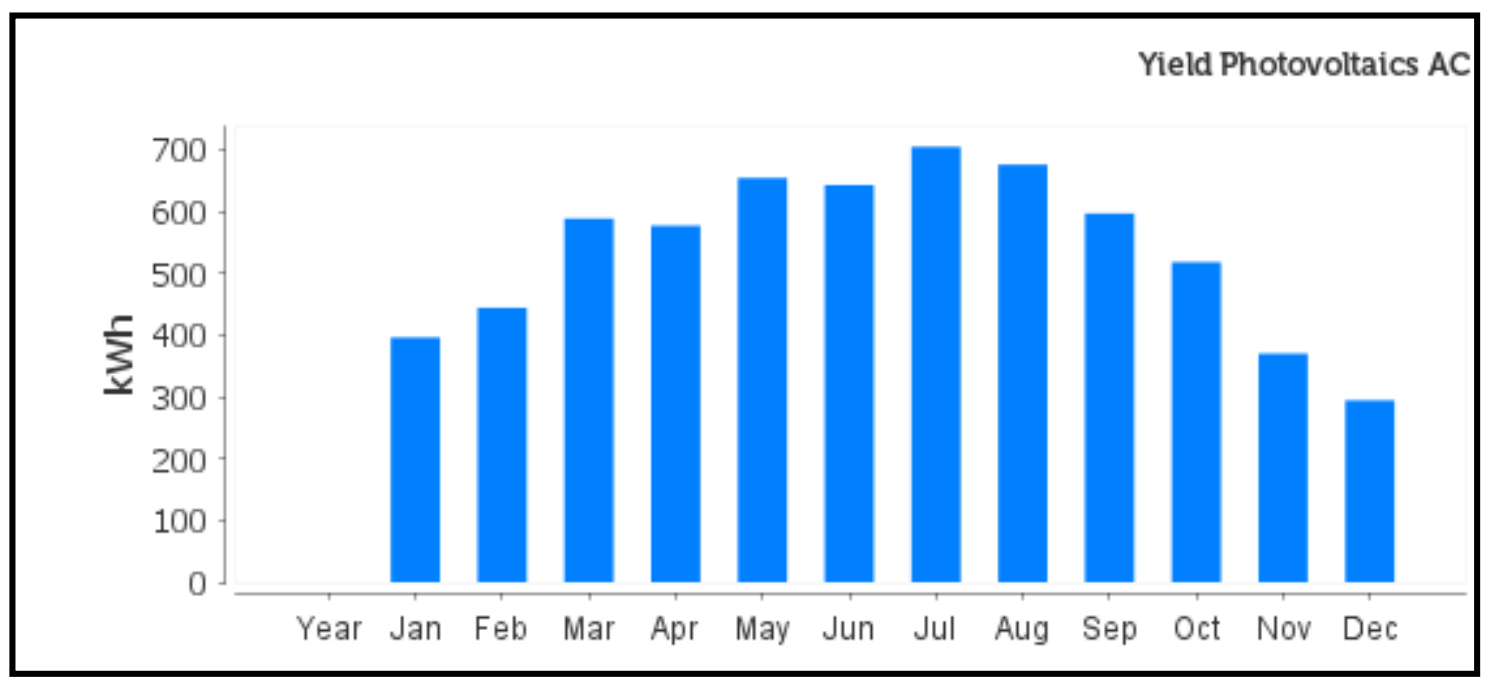

Figure 9. Photovoltaic yield of the system

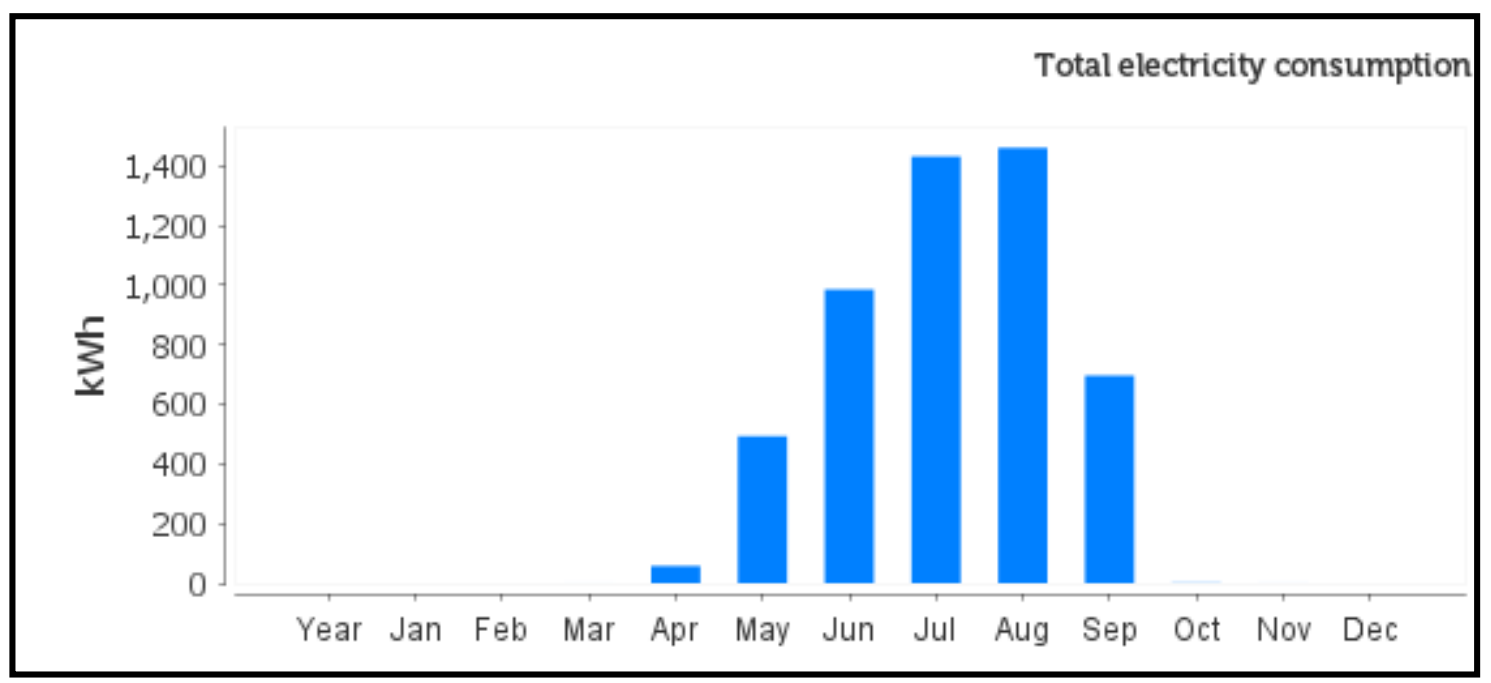

Figure 10. Total electricity consumption of the system

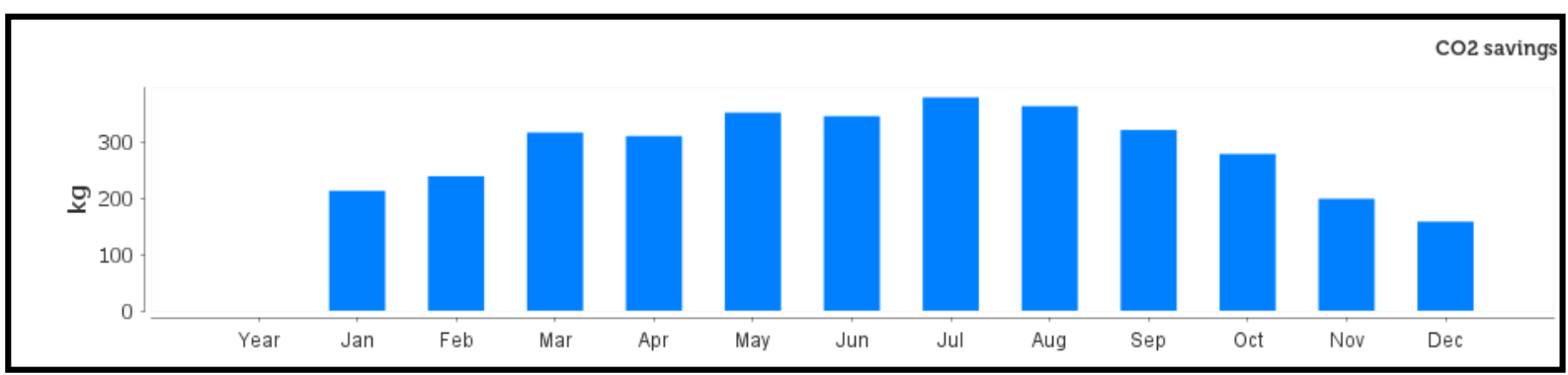

Figure 11. $\mathrm{CO}_{2}$ emission savings of the system 


\section{I Macrothink}

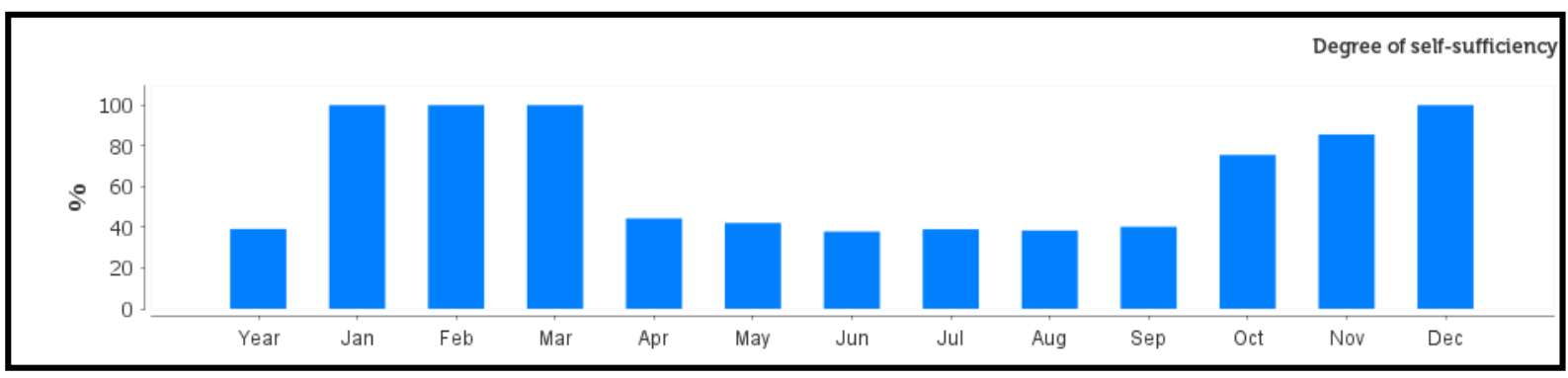

Figure 12. Degree of self-sufficiency of the system

Figure 12 unfolds that the system is self-sufficient throughout the year. It affirms that significant cooling utilization happens during the period of April to September at night. Thus, the cold storage basically requires a recharging towards the start of the day. In this way, the power used-up through the cooling of the machine surpasses the photovoltaic electricity produced in the first part of the daytime. Moreover, in the afternoon, traditional air-conditionings have everyday power utilization peaks, but the photovoltaic solar air-conditioning innovation delivers surplus of electricity. This implies that the proposed system innovation has a high potential application for future cooling. Figure 13 shows the graphical evaluation of the system performance output for the district of Rome.

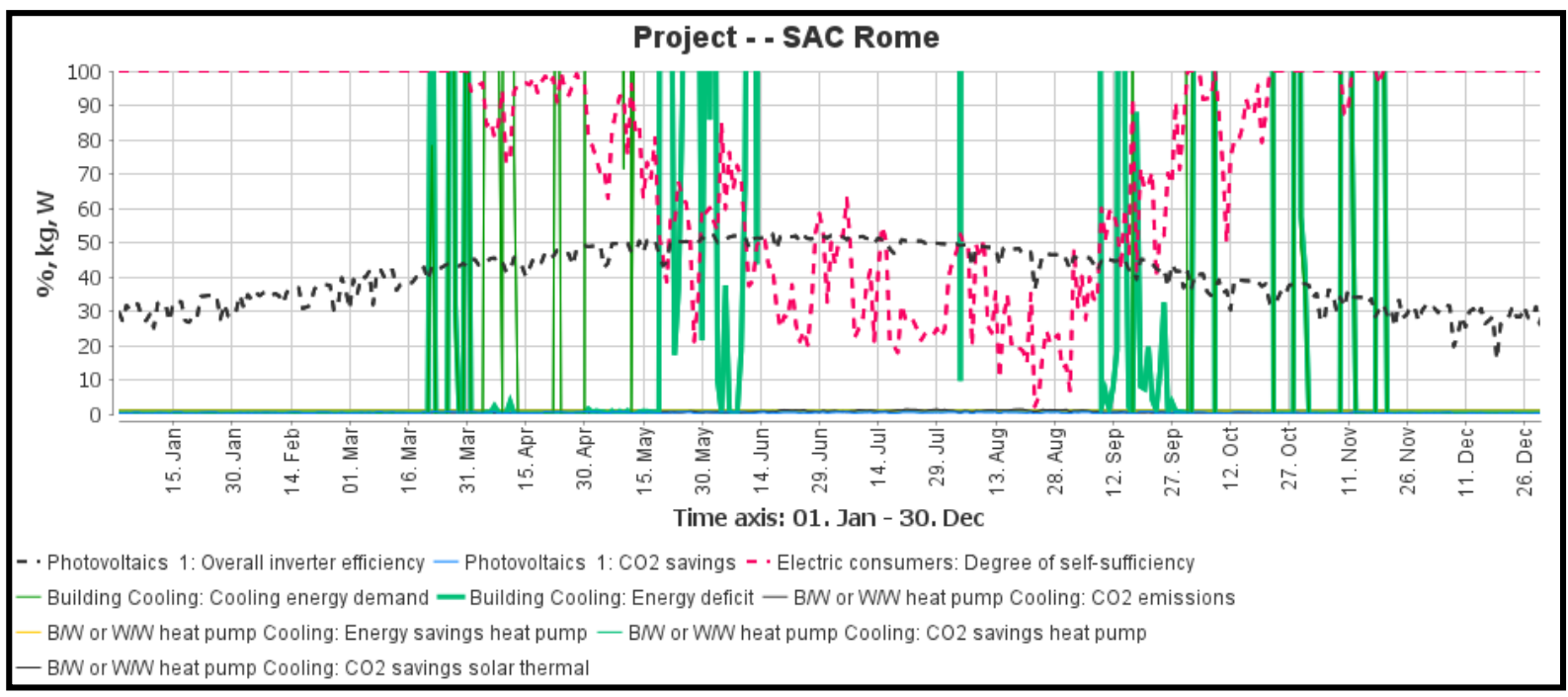

Figure 13. Graphical evaluation of the system performance output - Rome district

The greater part of the power overproduction transpires all through transitional times of cooling-to-warming seasons. During this time, the energy of air-conditioning and heating; for example, power requirements are low. However, a positive outside climate conditions decline the temperature contrast amongst the sub-systems of heat rejection and thusly is helpful for the cooling machine productivity in the preheating approach of domestic hot water. In springtime, power overproduction is particularly recognizable, and the photovoltaic power production is higher during the springtime than autumn. This is because of a lesser outdoor air-temperature during the springtime, which therefore expands the effectiveness of photovoltaic units. 
Moreover, Mauthner and Weiss (2014) and Oye et al., (2020b), suggest that majority of the solar air-conditionings are situated in specific European districts due to their climatic conditions. Hence, the simulations were constrained to London, Toulouse and Rome, and the weather information are obtained from meteonorm version 7.3 - the state-of-the-art meteorological database. The temperate and northern latitude of the three locations are given in Table 1.

Table 1. Climatic districts for solar air-conditioning

\begin{tabular}{|l|l|l|}
\hline Temperate & Location & Northern Latitude \\
\hline Oceanic, cold & London, UK & $52.5^{\circ} \mathrm{N}$ \\
\hline Mediterranean, mild & Toulouse, FR & $43.6^{\circ} \mathrm{N}$ \\
\hline Subtropical, hot & Rome, IT & $41.9^{\circ} \mathrm{N}$ \\
\hline
\end{tabular}

Subsequently, Table 2 presents the annual meteorological data analysis for the districts of London, Toulouse and Rome. The uncertainty of the year for London are $\mathrm{Gh}=3 \%, \mathrm{Bn}=6 \%$, $\mathrm{Ta}=0.3^{\circ} \mathrm{C}$ while the trend of $\mathrm{Gh} /$ decade is $5.1 \%$ and the variability of $\mathrm{Gh} /$ year is $6.5 \%$. The uncertainty of the year Toulouse are $\mathrm{Gh}=4 \%, \mathrm{Bn}=9 \%, \mathrm{Ta}=0.5^{\circ} \mathrm{C}$ while the trend of $\mathrm{Gh} /$ decade is $1.5 \%$ and the variability of $\mathrm{Gh} /$ year is $3.3 \%$. The uncertainty of the year for Rome are $\mathrm{Gh}=3 \%, \mathrm{Bn}=7 \%, \mathrm{Ta}=0.5^{\circ} \mathrm{C}$, while the variability of $\mathrm{Gh} /$ year is $3.7 \%$ respectively.

Table 2. Annual meteorological data analysis for London, Toulouse and Rome

\begin{tabular}{|l|l|l|l|l|}
\hline Parameter & Unit & London & Toulouse & Rome \\
\hline $\mathrm{Gh}$ & $\mathrm{kWh} / \mathrm{m}^{2}$ & 974 & 1348 & 1433 \\
\hline $\mathrm{Dh}$ & $\mathrm{kWh} / \mathrm{m}^{2}$ & 572 & 648 & 650 \\
\hline $\mathrm{Bn}$ & $\mathrm{kWh} / \mathrm{m}^{2}$ & 820 & 1304 & 1387 \\
\hline $\mathrm{Ta}$ & ${ }^{\circ} \mathrm{C}$ & 13.1 & 13.8 & 17.3 \\
\hline $\mathrm{Td}$ & ${ }^{\circ} \mathrm{C}$ & 6.9 & 8.6 & 10 \\
\hline $\mathrm{FF}$ & $\mathrm{m} / \mathrm{s}$ & 2.0 & 3.8 & 1.2 \\
\hline
\end{tabular}

Besides, the London district possess an oceanic temperate climate, with cool winters and mild summers. Despite the fact that the metropolitan yearly climate possesses moderate precipitation for the utilization of the proposed solar air-conditioning; the yearly averaging is less than district like Rome. Unlike Rome and Toulouse, London has several extended periods of cloudy skies and recurrent precipitation that is light mist-type, which can possibly account for the municipal rainy image. However, the climate of London like much of the United Kingdom districts is formed via the high latitude Atlantic Ocean of onshore flow, which in turn conveys cool, moist air, and regular skies that are cloudy. In the existing restrictions of London, the maximum temperature ever logged by the Met Office was $38.1^{\circ} \mathrm{C}$ and the coolest temperature ever logged was $-16.1^{\circ} \mathrm{C}$, recorded during the European Heat Wave at Kew Gardens. Unlike Rome and London districts, Toulouse region has a Mediterranean temperate climate which is mostly mild, and may be described as transitional Mediterranean, having hot, sunny summers and moderately mild winters. Nevertheless, there may be cold days in winter with temperatures below freezing and very hot days in summer. In the Haute-Garonne department, the metropolitan is situated in the south-west of France. The 
average temperature of the warmest month is around $22.3{ }^{\circ} \mathrm{C}$ and the coldest month is around $6{ }^{\circ} \mathrm{C}$. Unlike London and Toulouse, the district of Rome has a subtropical/ Mediterranean climate with some slight continentality elements. Winter is quite rainy and mild, nonetheless it can get cold at night. Winter season are cold in Rome, and the average low temperature drops to $2.8^{\circ} \mathrm{C}$ during winter peak while the summer periods are sunny and hot with a few afternoon thunderstorms, and the average high temperature can reach up to $27.8^{\circ} \mathrm{C}$. The weather information for London, Toulouse and Rome has been complied using meteonorm database which, in turn, includes appropriate meteorological data required for planning of solar applications.

Consequently, Table 3 present the annual results of the optimized system for the three locations. The comparison of energy results in association with the examined weather conditions of London, Toulouse and Rome districts are uncovered in Figure 14, Figure 15, Figure 16 and Figure 17. In the entirely three areas, the chart demonstrates that the cooling systems are expected to sustain the comfort conditions of the building.

Table 3. Annual system improvement performance results (Oye et al., 2020b)

\begin{tabular}{|l|l|l|l|l|}
\hline System & Unit & London & Toulouse & Rome \\
\hline System Performance & - & 3.97 & 3.64 & 3.45 \\
\hline Self-consumption & $\mathrm{kWh}$ & 4651.9 & 6315.9 & 6468.5 \\
\hline Yield of PV AC & $\mathrm{kWh}$ & 824 & 1448 & 2010 \\
\hline To external grid & $\mathrm{kWh}$ & 3828 & 4868 & 4458 \\
\hline From external grid & $\mathrm{kWh}$ & 1377 & 1918 & 3119 \\
\hline Heat generator energy to the system & $\mathrm{kWh}$ & 10976 & 15556 & 22749 \\
\hline Total energy consumption & $\mathrm{kWh}$ & 8675 & 12176 & 17658 \\
\hline Energy deficit & $\mathrm{kWh}$ & 1361 & 3490 & 6235 \\
\hline Total fuel and/ or electricity consumption & $\mathrm{kWh}$ & -2465.2 & -2967.4 & -1357.5 \\
\hline Total electricity consumption & $\mathrm{kWh}$ & 2201 & 3366 & 5130 \\
\hline Primary energy factor & $\mathrm{kWh}$ & 0.28 & 0.28 & 0.32 \\
\hline Degree of self-sufficiency & $\%$ & 37.4 & 43 & 39.2 \\
\hline $\mathrm{CO}_{2}$ Savings & $\mathrm{kg}$ & 2495 & 3388 & 3470 \\
\hline
\end{tabular}

Moreover, the cooling request in the Mediterranean and subtropical climate is a lot higher than the oceanic climate. In this way, the examination demonstrates that the cooling demand for the three locations are covered, and air-conditioning is required or else the living room temperature will never be comfortable. 


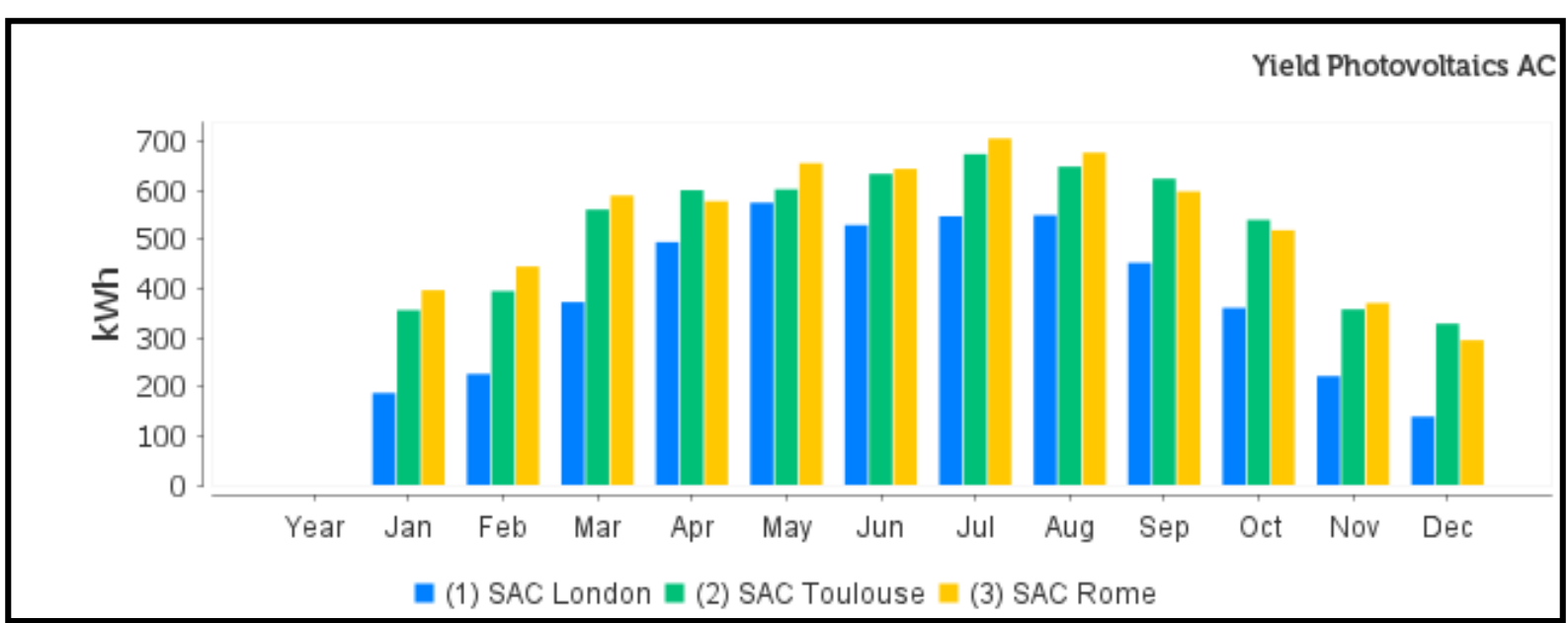

Figure 14. Photovoltaic yield of the system

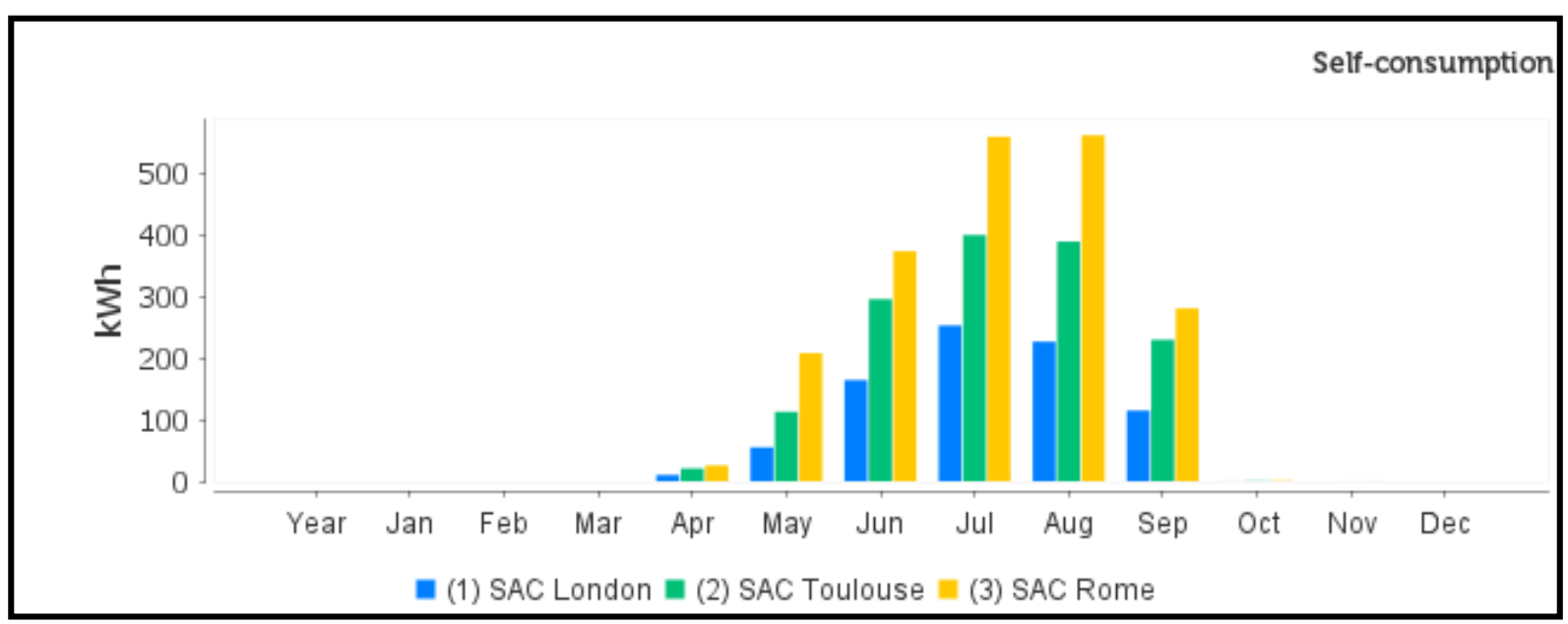

Figure 15. Self-consumption of the system

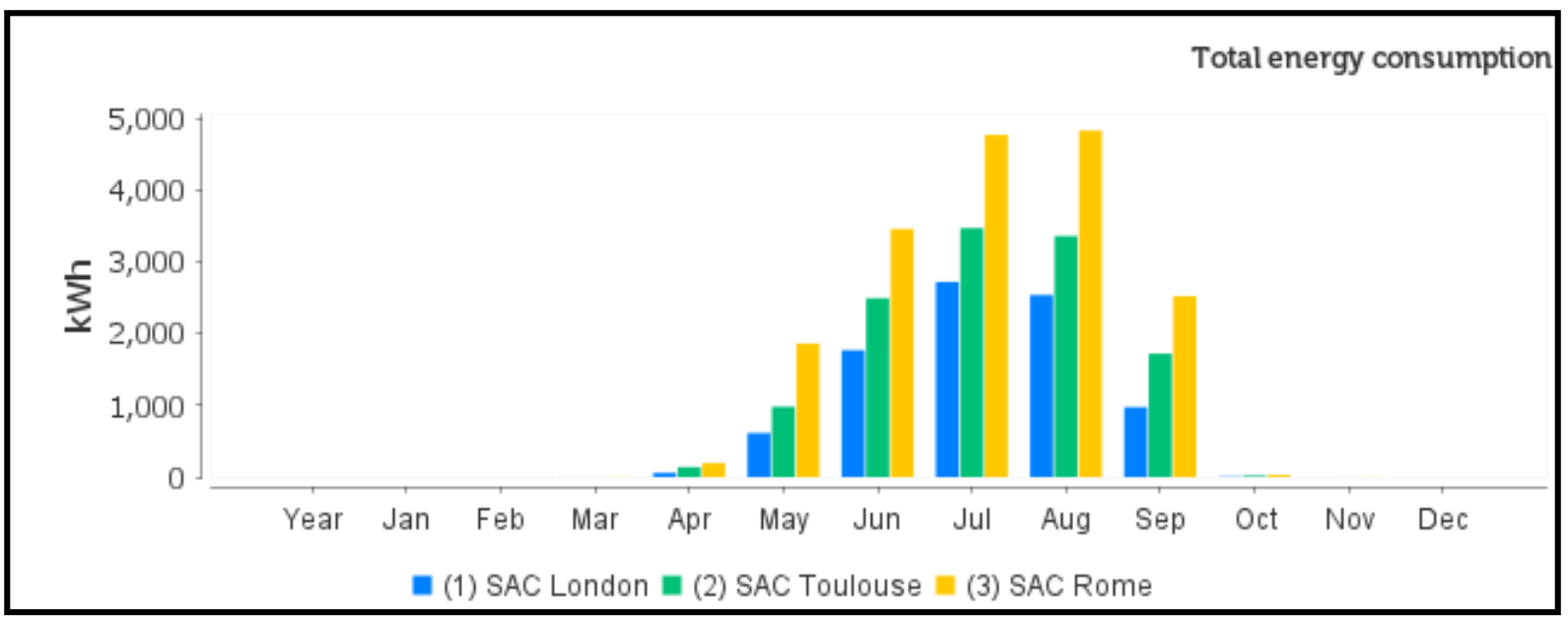

Figure 16. Total energy consumption of the system 


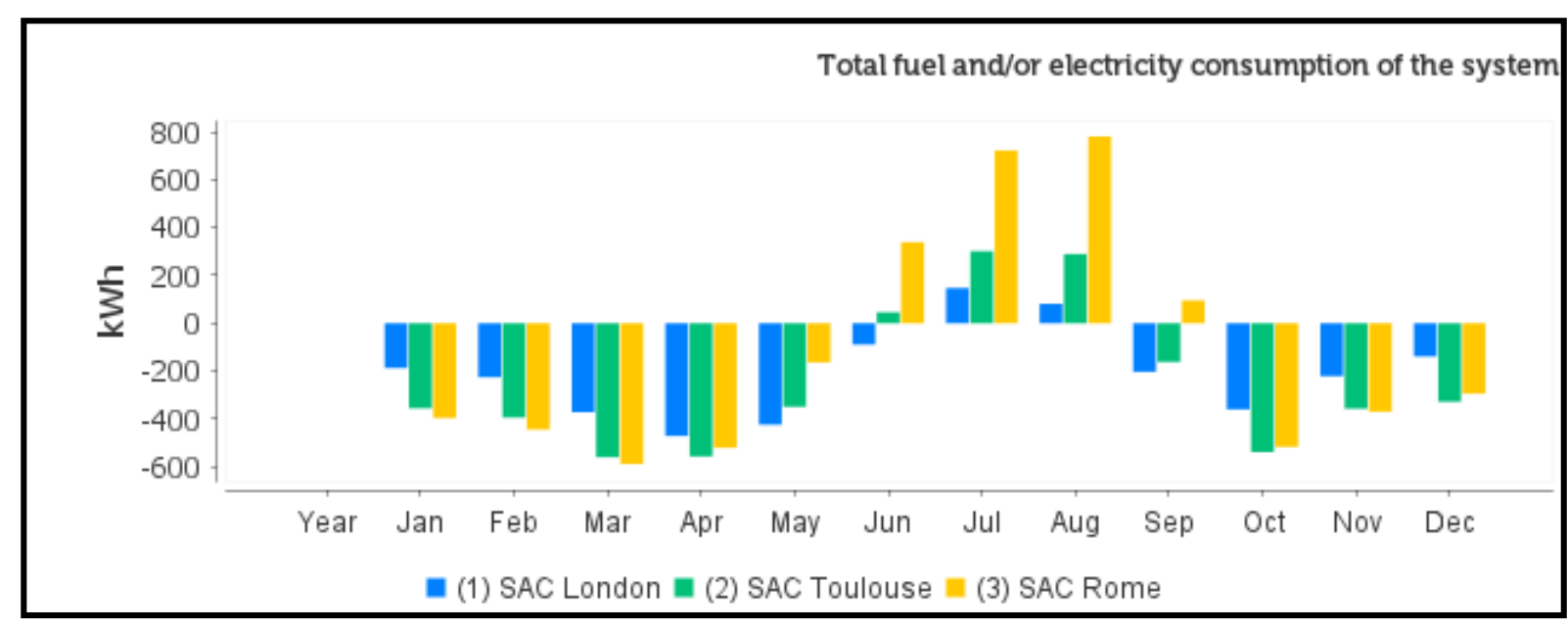

Figure 17. Total fuel and electricity consumption of the system

However, operating the system during a period of non-cooling season is a procedure of lesser proficiency in view of adverse levels of temperature. On account of higher outdoor heat gains and interior loads - this system will give the room temperature a chance to ascend out of the range of comfort which might exasperate the circumstance in wet climate. The extent of the complete power request secured through photovoltaic solar air-conditioning in Rome and Toulouse is higher than in London. This is because the photovoltaic power generation well-complements the yearly power request and subsequently, there is system lesser off-time considering constraints of freezing. In any case, a delayed and ceaseless cold production prompts the heat rejection overheating, which in turn enables high open-air temperature that increases temperature of the heat rejection and subsequently makes the cooling machine execution turnout to be more hostile. However, the optimized system performance in the three districts substantiated to decrease $\mathrm{CO}_{2}$ emissions and energy consumption.

\section{Conclusion}

The components of the solar air-conditioning are optimized in Polysun program and the results unveiled that the system can provide the required yearly energy yield without compromise. In the temperate hot and cold region of Rome and London respectively, a little cooling power shortage will occur, and the temperature of the room will surpass the set point. The power increase of the system will diminish the peak of room temperature on the grounds that the system activity time at ostensible load transpires, which can be rare. In Toulouse and Rome, the distinction in span of cooling seasons is similar. The open-air temperature below extreme freezing temperature in the period of winter may be enduring. In London, heat generation and domestic hot water are in a smaller amount than in climatic locale that is hot. These instances unfold that the system innovation units, for example, carriers of heat and cooling machine may be supplanted. Also, the mechanisms are to work at lesser temperatures, and this will be progressively coherent in a non-cooling season for accessibility of photovoltaic power utilization at the operation of the system in London climate conditions. Hence, a higher power of heating is mandatory in temperate cold climatic areas. For the low temperature of the outdoor can enhance the performance of the system. 
Consequently, the analysis outcome established that solar air-conditioning can cover the proposed cooling demand through the improved system performance. It identifies the degree to which the sustainability of renewable air-conditioning is green. In particular, based on renewable energies; solar power as alternatives to fossil fuels and contribution this alternative source of energy makes to embrace sustainable future developments in structuring, selecting and sustaining an environmentally friendly system. Therefore, the optimized system significantly demonstrates the importance of using solar energy to power air-conditioning systems in London, Toulouse and Rome districts. This, in turn, reveals the particular contribution renewable makes to reduce the level of energy consumption and rate of carbon emissions. It means that for this paper, renewables are the fundamental key components of the air-conditioning as they promote to reduce levels of energy consumption and lower carbon emissions, vis-à-vis establish a comfortable and healthy indoor environment as an exercise in the optimized development of renewable air-conditioning whose status produce sustainable-based future districts and more climate resilience.

\section{References}

Aftab, M., Chau, C., \& Armstrong, P. (2013). Smart air conditioning control by wireless sensors: an online optimization approach. In proceedings of the fourth international conference on future energy systems, e-Energy '13, New York, NY, USA. pp. 225-236. https://doi.org/10.1145/2487166.2487192.

Armstrong, M. (2018). Energy storage. Growing demand for air conditioning - and energy. Number of AC units worldwide and corresponding energy demand. [Online] Available: https://www.statista.com/chart/14401/growing-demand-for-air-conditioning-and-energy/

Broman, L. (1991). A concentrated course in solar thermal process engineering. Proc of the ISES Solar World Congress, Denver, Colorado, Pergamon Press. pp. 3815-3820.

Buonomano, A., Calise, F., \& Palombo, A. (2018). Solar heating and cooling systems by absorption and adsorption chillers driven by stationary and concentrating photovoltaic/thermal solar collectors: Modelling and simulation. Renewable and Sustainable Energy Reviews, 81, 1112-1146. https://doi.org/10.1016/j.rser.2017.07.056

Cooling Machine Manufactory. (2019). The Cooling Machine Manufactory. World class solutions in sustainable energy. Contributing to a more sustainable world with solution for indoor climate and comfort. Nibe Industrier. [Online] Available: www.nibe.com

Dempsey, N., Bramley, G., Power, S., \& Brown, C. (2011). The social dimension of sustainable development: defining urban social sustainability. Sustainable Development, 19, 289-300. https://doi.org/10.1002/sd.417

EC. (2009). Directive 2009/28/EC of the European Parliament and of the Council of 23 April 2009 on the promotion of the use of energy from renewable sources and amending and subsequently repealing Directives 2001/77/EC and 2003/30/EC.

EC. (2010). Directive 2010/31/EU of the European Parliament and of the Council of 19 May 2010 on the energy performance of buildings. 


\section{Macrothink}

Environmental Management and Sustainable Development

ISSN 2164-7682

2020, Vol. 9, No. 3

Ford, D., \& Berrang-Ford, L. (2011). Climate Change Adaptation in Developed Nations: From Theory to Practice; Springer: Dordrecht, The Netherlands, pp. 490.

https://doi.org/10.1007/978-94-007-0567-8

Gugulothua, R., Somanchi, N. S., Banoth, H. B., \& Banothu, K. (2015). A Review on Solar Powered Air Conditioning System. Global Challenges, Policy Framework and Sustainable Development for Mineral and Fossil Energy Resources (GCPF2015). Procdia arth and planetary science, 11, 361-367. https://doi.org/10.1016/j.proeps.2015.06.073

Hadj, A. M. A., Benhaoua, B., \& Balghouthi, M. (2015) Simulation of tubular adsorber for adsorption refrigeration system powered by solar energy in sub-Sahara region of Algeria. Energy Conversion and Management, 106, 31-40.

https://doi.org/10.1016/j.enconman.2015.09.013

Hao, E. K. J., \& GhaffarianHoseini, A. (2012). Solar vs. Conventional Air-Conditioning Systems: Review of LIMKOKWING University Campus, Cyberjaya, Malaysia. Journal of Creative Sustainable Architecture \& Built Environment, 2.

Henning, H. M. (2009). Solar assisted air conditioning of buildings - an overview. Appl. Therm. Eng., 27, 17341749.

Henning, H. M., Erpenbeck, T., Hindenburg, C., \& Santamaria, I. S. (2001). The potential of solar energy use in desiccant cooling cycles. International Journal of Refrigeration, 24, 220-229. https://doi.org/10.1016/S0140-7007(00)00024-4

Holst, A. (2020). Air conditioner demand worldwide from 2012 to 2018, by region (in millions). Demand for air conditioners in the Chinese market stood at 44.63 million units. [Online] Available:

https://www.statista.com/statistics/871535/worldwide-air-conditioner-demand-by-region/

IPCC. (2007). Climate Change 2007, In: Solomon S, et al., editors, The physical science basis. Contribution of the working group I to the fourth assessment report of the intergovernmental panel on climate change, Cambridge/

Islam, M. P., \& Morimoto T. (2016). Thermodynamic performances of a solar driven adsorption system. Solar Energy, 139, 266-277. https://doi.org/10.1016/j.solener.2016.09.003

Jafari, A., \& Poshtiri, A. H. (2017). Passive solar cooling of single-storey buildings by an adsorption chiller system combined with a solar chimney. Journal of Cleaner Production, 141, 662-682. https://doi.org/10.1016/j.jclepro.2016.09.099

Jakob, U. (2013). Status and perspective of solar cooling in Europe. Australian Solar Cooling 2013 Conference. Sydney, Australia: CSIRO Riverside Life Sciences Centre, pp. 30.

Kandpal, T. C., \& Broman, L. (2015). Renewable energy education: a worldwide status review. Strömstad: Strömstad Akademi. https://doi.org/10.1016/j.rser.2014.02.039

Kjellström, T., Holmer, I., \& Lemke, B. (2009). Workplace heat stress, health and productivity an increasing challenge for low-and middle-income countries during climate 
change. Glob. Health Action 2009. https://doi.org/10.3402/gha.v2i0.2047

Masson, G., Orlandi, S., \& Rekinger, M. (2014). Global Market Outlook for Photovoltaics 2014-2018. Brussels, Belgium: European Photovoltaic Industry Association, pp. 60.

Mauthner F., \& Weiss W. (2014). Solar Heat Worldwide Markets and Contribution to the Energy Supply. Gleisdorf, Austria: IEA Solar Heating \& Cooling Programme, pp. 61. https://doi.org/10.18777/ieashc-shw-2014-0001

Milrad, M. (2013). Seamless Learning: An International Perspective on Next Generation Technology Enhanced Learning. In Z. L. Berge \& L. Y. Muilenburg (Eds.), Handbook of Mobile Learning.

Mouchot, A. (1869). La Chaleur solaire et ses applications industrielles. Paris, France: Gauthier-Villars, pp. 260.

Mouchot, A. (1987). Die Sonnenwärme und ihre industriellen Anwendungen. Oberbözberg, Switzerland: Olynthus-Verlag, pp. 224.

Mugnier, D., (2013). New generation solar cooling \& heating systems. Task description and Work plan. IEA Solar Heating \& Cooling Programm, pp. 30.

Oye, T. T., Goh, K., Gupta, N., \& Oye, T. K. (2020a). Assessment of Renewable Air-Conditioning Using Economic Feasibility Procedures. International Journal of Innovative Science and Research Technology, 5(3).

Oye, T. T., Gupta, N., Goh, K., \& Oye, T. K. (2020b). Theoretical Assessment of Sustainability Principles for Renewable Smart Air-Conditioning. Environmental Management and Sustainable Development, 9(3), 18-46. https://doi.org/10.5296/emsd.v9i3.16953

Polysun program. (2020). Vela Solaris Polysun Designer Version. Design of reliable and holistic energy systems. For Buildings and districts with a future. [Online] Available:

https://www.velasolaris.com/?lang=en

Rafique, M. M., \& Rehman, A. (2018). Renewable and Sustainable Air Conditioning, IntechOpen. https://doi.org/10.5772/intechopen.73166

Ritchie, H., \& Roser, M. (2019). Energy Access. Energy production by region. Primary energy consumption by source, world, 1965 to 2019. [Online] Available:

https://ourworldindata.org/energy

Sanner, B., Kalf, R., Land, A., Mutka, K., Papillon, P., Stryi-Hipp, G., \& Weiss, W. (2011). Common Vision for the Renewable Heating \& Cooling sector in Europe. - Brussels, Belgium: Renewable Heating \& Cooling, pp. 48.

Sayigh. A. (2018). The World Renewable Energy Congress/ Network. [Online] Available: www.wrenuk.co.uk

Schulte, P. A., \& Chun, H. (2009). Climate change and occupational safety and health: Establishing a preliminary framework. J. Occup. Environ. Hyg., 6, 542-554. 
https://doi.org/10.1080/15459620903066008

Solar Heat Worldwide. (2018). Global Market Development and Trends in 2017. IEA (International Energy Agency) Solar Heating and Cooling Programme. [Online] Available: https://www.iea-shc.org/Data/Sites/1/publications/Solar-Heat-Worldwide-2018.pdf

Solar Heat Worldwide. (2020). Global Market Development and Trends in 2019. IEA (International Energy Agency) Solar Heating and Cooling Programme. [Online] Available: https://www.iea-shc.org/Data/Sites/1/publications/Solar-Heat-Worldwide-2020.pdf

Solar Power Europe. (2020). The solar power Europe. EU solar boom: over 100\% solar market increase in 2019. [Online] Available:

https://www.solarpowereurope.org/eu-solar-boom-over-100-solar-market-increase-in-2019/

Vasta, S., Palomba, V., Frazzica, A., Di Bella, G., \& Freni, A. (2013). Techno-economic analysis of solar cooling systems for residential buildings in Italy. Journal of Solar Energy Engineering, 135, 021002.

Vougiouklakis, Y., Theofilidi, M., \& Korma, E. (2008). Report on market situation \& trends about small scale chillers. WP2: Market Analysis. Pikermi Attiki, Greece: Centre for renewable energy sources, pp. 29.

Watts, J. (2019). How global heating is causing extreme weather. Heat headlines not focusing enough on climate crisis reality - experts. [Online] Available:

https://www.theguardian.com/uk-news/2019/aug/27/holiday-heat-headlines-not-focusing-eno ugh-on-climate-crisis-reality-experts

Yu, B. F., Hu, Z. B., Liu, M., Yang, H. L., Kong, Q. X., \& Liu, Y. H. (2008). Review of research on air-conditioning systems and indoor air quality control for human health. International journal of refrigeration, 32, 3-20. https://doi.org/10.1016/j.ijrefrig.2008.05.004

Yu, C., \& Lin, C. (2015). An Intelligent Wireless Sensing and Control System to Improve Indoor Air Quality: Monitoring, Prediction, and Pre-action. International Journal of Distributed Sensor Networks, 2015, 1-9. https://doi.org/10.1155/2015/140978

Zhang, N., Lior, N., \& Han, W. (2016). Performance study and energy saving process analysis of hybrid absorption compression refrigeration cycles. Journal of Energy Resources Technology, 138, 061603. https://doi.org/10.1115/1.4034589

\section{Copyright Disclaimer}

Copyright for this article is retained by the author(s), with first publication rights granted to the journal.

This is an open-access article distributed under the terms and conditions of the Creative Commons Attribution license (http://creativecommons.org/licenses/by/4.0/). 